\title{
造影剂腎症の発現機序解明による予防薬の探索研究
}

\author{
千堂年昭a,b
}

a岡山大学病院 薬剂部, b岡山大学大学院医歯薬学総合研究科 臨床薬剂学

キーワード：造影剂腎症, アポトーシス, サイクリック AMP, ベラプロスト

\section{Experimental evidence for prevention of acute renal failure induced by radiographic contrast medium}

Toshiaki Sendo ${ }^{\mathrm{a}, \mathrm{b}}$

aDepartment of Pharmacy, Okayama University Hospital,

${ }^{\mathrm{b}}$ Department of Clinical Pharmacology and Pharmacy, Okayama University Graduate School of Medicine, Dentistry and Pharmaceutical Sciences

\section{はじめに}

X線造影技術は近年目覚しい発展を遂げ，それに伴 い造影剤の使用は増加の一途を辿っている. ヨード造 影剂はX線の吸収を高める優れた陽性造影剤である が，注入直後に紅斑や萇麻疹などの過敏症状が発現す ることがあり, 時として呼吸困難, 肺水腫, 意識消失, 心停止といった重篤なショック症状を引き起こすこと もある。また, 投与数日以内に紅斑や発疹, 悪心など の遅発型過敏反応を引き起こすことがある. 一方, 造 影剤は, 造影剂腎症と呼ばれる急性の腎障害を引き起 こすことが知られている。造影剤腎症は患者の QOL を低下するだけでなく, 入院延長に伴う医療費増大と いう医療経済面でも重大な問題となる。特に, 糖尿病 などにより腎機能が低下している患者や, 抗腫瘍薬や 抗菌薬, 解熱鎮痛薬などを使用している患者, または 高齢者などにおいては, その発症頻度は10～30\%と非

\section{平成 21 年 5 月受理}

T700-8558 岡山市北区鹿田町 2-5-1

電話：086-235-7640 FAX：086-235-7794

E-mail : sendou@md.okayama-u.ac.jp
常に高く, 代表的な薬剤性腎症の一つとなっている. 造影剤腎症の発症機序に関しての詳細は不明である が，造影剤の投与によって腎血管が収縮し，腎血流量 や糸球体濾過量が低下するため，血管性の要因が考え られている。さらに，造影剂は尿細管細胞に対して直 接的な細胞毒性を示すことも知られている。造影剂腎 症の予防薬としての有効性を調べる目的で，これまで に数多くの薬剤について臨床試験が実施されてきた が，残念ながら，臨床での有用性が証明されたものは ほとんどなく，唯一認められている予防法は大量の輸 液による腎臓からの排泄促進である.

本稿では, 培養腎尿細管細胞を用いて, 造影剂腎症 の発症にいたる細胞内シグナル伝達経路の解明に基づ いた予防薬探索について概説する.

\section{造影剤による腎細胞アポトーシス誘導とカスパーゼの 役割')}

ブ夕近位尿細管由来細胞（LLC-PK1 細胞）を $100 \mathrm{mg}$ ヨード/mlの濃度の造影剂曝露により,アポトーシス初 期の指標であるホスファチジルセリンを特異的に染色 するAnnexin V染色や，障害された核を染色する

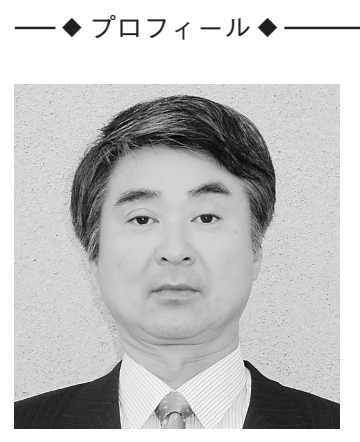

1985年 九州大学大学院薬学研究科博士課程修了

1985年－1987年 米国カンサス大学薬学部博士研究員

1987年 九州大学病院薬剂部薬剂師

2003年九州大学病院薬剂部 副薬剂部長

2005年 岡山大学病院 准教授・副薬剂部長

2008年 岡山県病院薬剤師会会長

2009年岡山大学病院 教授・薬剤部長 治験センター長

専門領域: 臨床薬理学, 臨床薬剂学, 医薬品情報解析学

研究テーマ: 医薬品の有害作用発現機序の解明と予防策に関する研究

(とくに造影剤, 抗がん薬, 脂質低下剂, 免疫抑制薬)

医薬品の有害事象発症リスクの解析に関する研究

薬物代謝酵素の遺伝子型判定と薬物治療の個別化

快・不快状況時の神経細胞情報伝達経路の解明 
TUNEL 染色において陽性を示す細胞が顕著に増加し たこと, DNAの断片化が認められたことから,この 細胞障害はアポトーシスによるものと考えられる。ま た, 造影剤（本研究では非イオン性造影剤, イオベル ソールを使用）による DNA 断片化は, 非特異的なカ スパーゼ阻害剤, カスパーゼ 3 阻害剤およびカスパー ゼ 9 阻害剤の前処置によって消失したが, カスパーゼ 8 阻害剤では影響されない。この結果と一致して, 造 影剤曝露により細胞内カスパーゼ 3 および 9 の活性が 顕著にえ進していた（図１）。さらに, 造影剤曝露によ りアポトーシス抑制因子である bcl-2 mRNA 発現の 低下およびアポトーシス促進因子である bax mRNA 発現の増加が観察された (図 2 )。したがって, 造影剤 は腎尿細管細胞に直接作用し, $\mathrm{Bcl}-2$ の発現量を低下 し, Bax 発現量を増加することによって, カスパーゼ9 およびカスパーゼ- 3 を活性化し, アポトーシスを引 き起こすと考えられた。

\section{ヨード造影剤によるカスパーゼ活性化に対する cAMP の保護作用 ${ }^{2,3)}$}

Bcl-2 遺伝子には cAMP-responsive element (CRE) と呼ばれる転写調節領域が存在し,この部位に CRE 結 合タンパク (CREB) が結合すると bcl-2 発現量が増 加することが知られている. CREB は通常, 細胞質に 存在し, リン酸化されることで核内に移行し CRE に 結合する.この CREB のリン酸化に関与する細胞内シ グナルの一つに $\mathrm{cAMP} / \mathrm{A}$ キナーゼ系がある.そこで,
細胞内 cAMPを増加させることにより造影剤による アポトーシスが抑制されるであろうと考え，造影剤誘 発細胞障害に対する非加水分解性 cAMP アナログの ジブチリル cAMP (DBcAMP) や $\mathrm{PGI}_{2}$ アナログのベ ラプロストの作用について検討した。その結果，いず
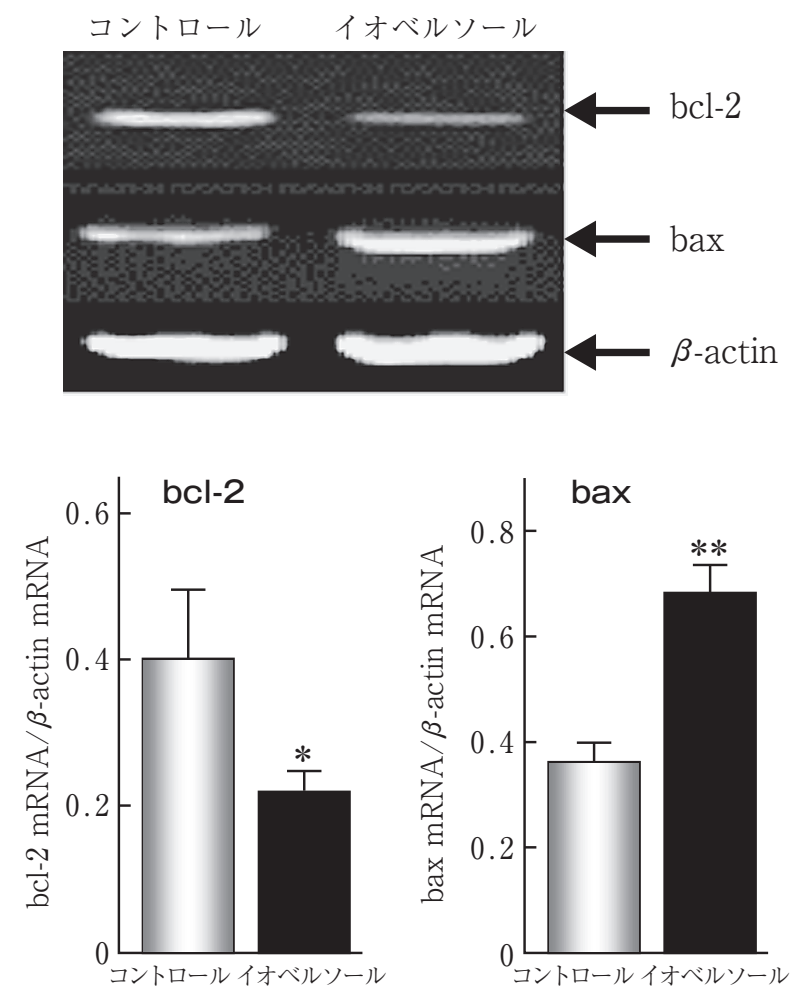

図 2 LLC-PK 1 細胞におけるイオベルソール誘発 bcl-2 mRNA 発現低下作用ならびに Bax mRNA 発現増加作 用 $(* \mathrm{p}<0.05, * * \mathrm{p}<0.01)$ (文献 1 より引用)

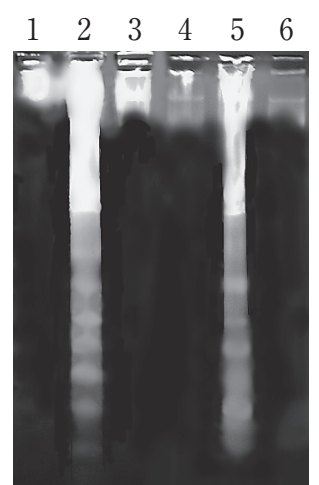

1 : コントロール

2 : イオベルソール $100 \mathrm{mgl} / \mathrm{ml}$

$3:+$ 非特異的カスパーゼ阻害剤 $(30 \mu \mathrm{M})$

$4:$ ，カスパーゼ 3 阻害剂 $(50 \mu \mathrm{M})$

5 : +カスパーゼ 8 阻害剂 $(50 \mu \mathrm{M})$

$6:+$ カカパーゼ 9 阻害剤 $(50 \mu \mathrm{M})$

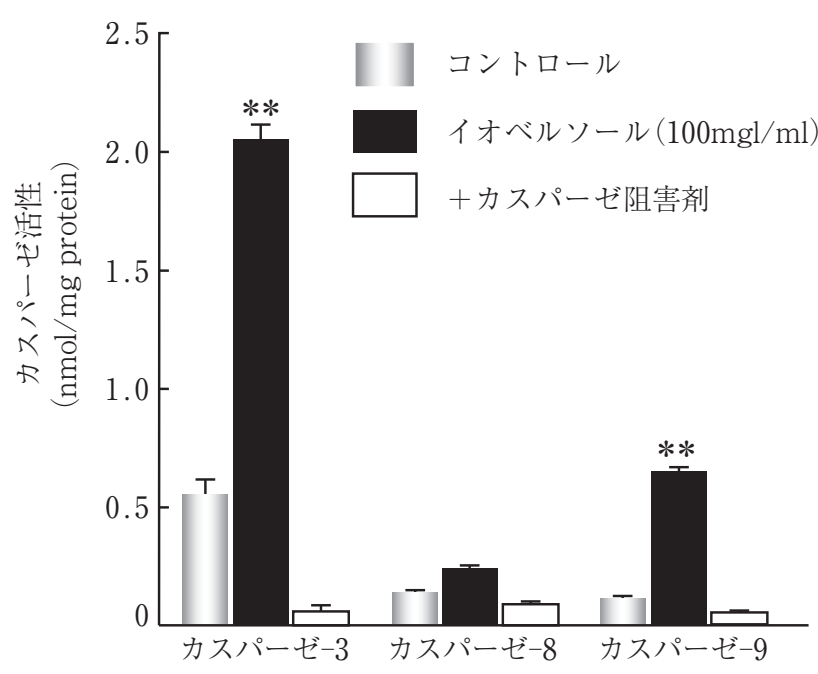

図 1 イオベルソールによる DNA 断片化およびカスパーゼ-3ならびにカスパーゼ-9 活性化 $\left({ }^{* *} \mathrm{p}<0.01\right)$ (文献 1 より引用) 
れも，造影剤による尿細管細胞障害を保護するととも に, 造影剤による bcl-2 mRNA 発現低下, カスパーゼ 9 およびカスパーゼ 3 の活性化を抑制することが明ら かとなった（図 3 ).ささらに, DBcAMP やベラプロス トにより尿細管細胞において顕著な CREB リン酸化 が認められた。また，ベラプロストによる細胞保護作 用と細胞内 $\mathrm{cAMP}$ 濃度の上昇とは濃度的によく一致 していたことから（図 4)，尿細管における $\mathrm{cAMP} /{ }^{2}$ ロテインキナーゼ $\mathrm{A} / \mathrm{CREB}$ 系の活性化が造影剂腎症 の予防に有効であろうと考えられた。

一方, プロテインキナーゼAから CREB リン酸化に
至る経路にホスファチジルイノシトール 3 -キナーゼ/ Akt の経路が関与すること, 造影剂が Akt のリン酸化 を抑制することも明らかになった。また，cAMPによ る保護作用における CREB リン酸化の関与を明確に するために, 不活性化 CREB を導入した細胞を用いて 検討した結果，造影剂に対する DBcAMP の保護作用 は細胞生存率のみならず bcl-2, bax mRNA 発現変化 においても完全に消去された（図 5 )。したがって，造 影剤は Akt リン酸化を抑制することにより, CREB リ ン酸化抑制 $->$ bcl-2 発現低下 $->b a x$ 発現増加 $->$ カスパーゼ活性化ー>核障害の経路によりアポトーシ
DNA 断片化

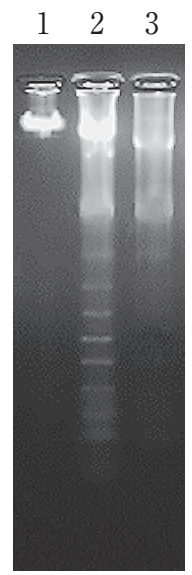

1 : 無処置

2 : イオベルソール

$(100 \mathrm{mgl} / \mathrm{ml})$

$3:+$ ベラプロスト $(1 \mu \mathrm{M})$

\section{カスパーゼ活性}

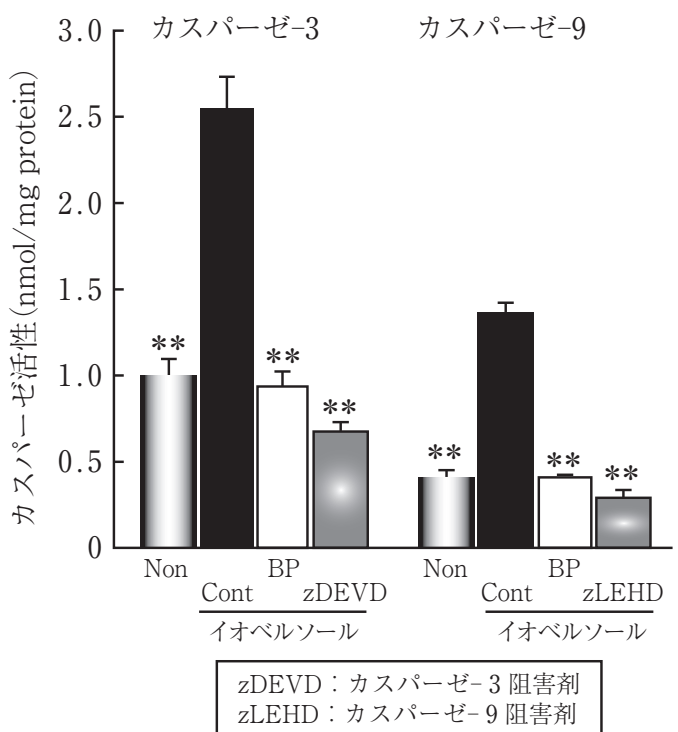

mRNA 発現

bcl-2 bax
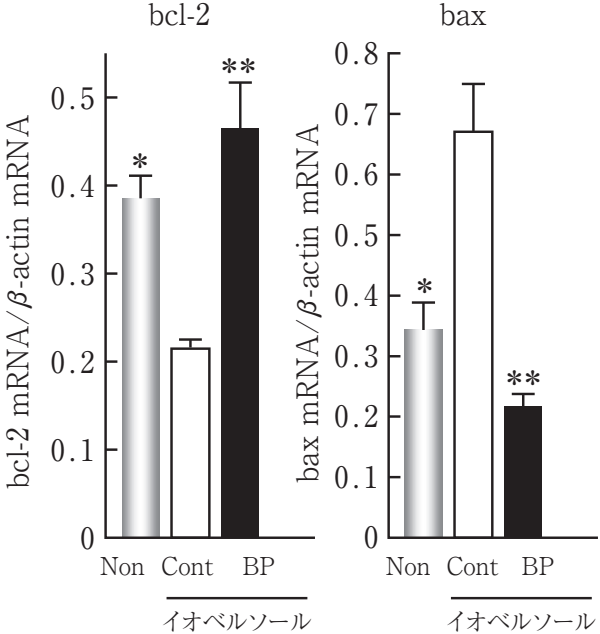

図 3 イオベルソール誘発 LLC-PK 1 細胞障害に対するベラプロスト $(\mathrm{BP})$ の保護作用 $\left({ }^{*} \mathrm{p}<0.05,{ }^{* *} \mathrm{p}<0.01 ） （\right.$ 文献 2 より引用 $)$
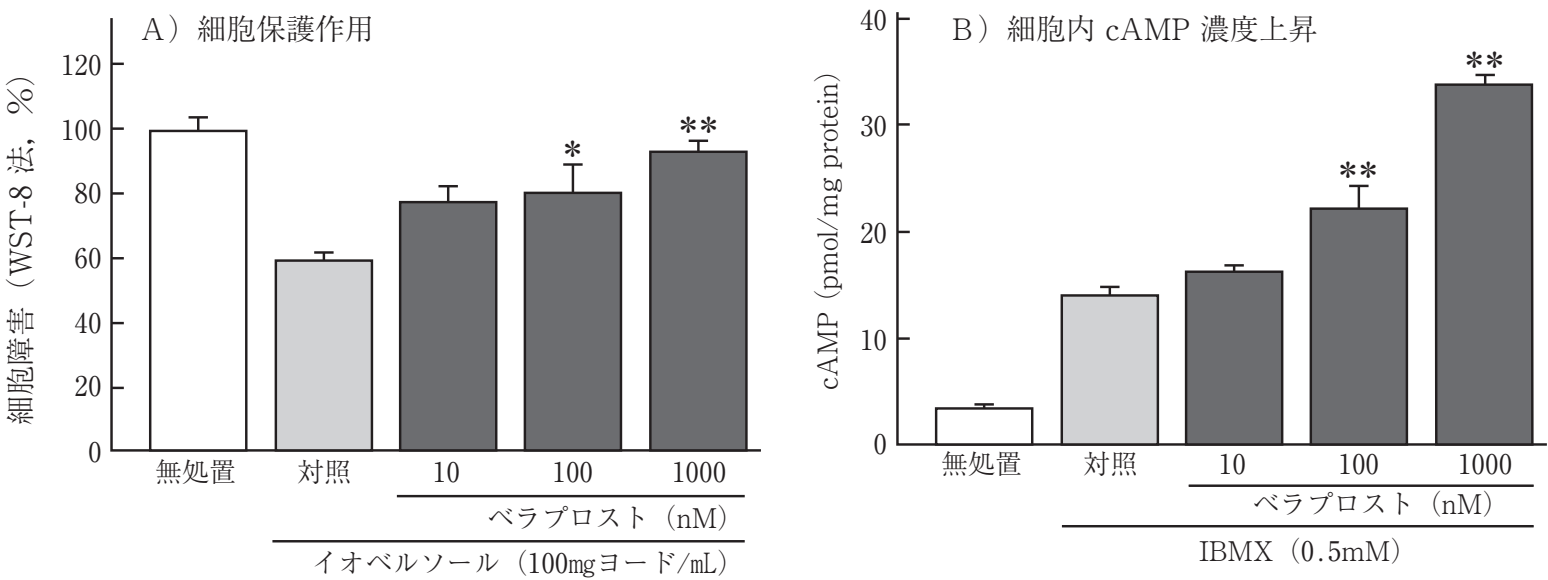

図 4 イオベルソールによる LLC-PK 1 細胞障害に対するべラプロストの保護作用（A）ならびにベラプロストによる細胞内 cAMP 濃度増加作用（B）（文献 2 より引用） 
スを引き起こすと考えられた（図 6 ).

\section{造影剤腎症マウスにおけるべラプロストの保護作用 ${ }^{4)}$}

In vitro 実験（培養細胞）系で得られた結果が, in vivo（動物）においてもあてはまることを確認するた め, マウスを用いて造影剤腎症モデルを作成し, ベラ プロストによる保護作用について検討した。片腎を結 紮したマウスに造影剤 ( $4 \mathrm{~g}$ ヨード $/ \mathrm{kg})$ を静脈内投与 すると，24時間後には尿中 NAG 活性が顕著に増加し た。一方，腎組織を TUNEL 染色したところ，尿細管
Bcl-2 mRNA
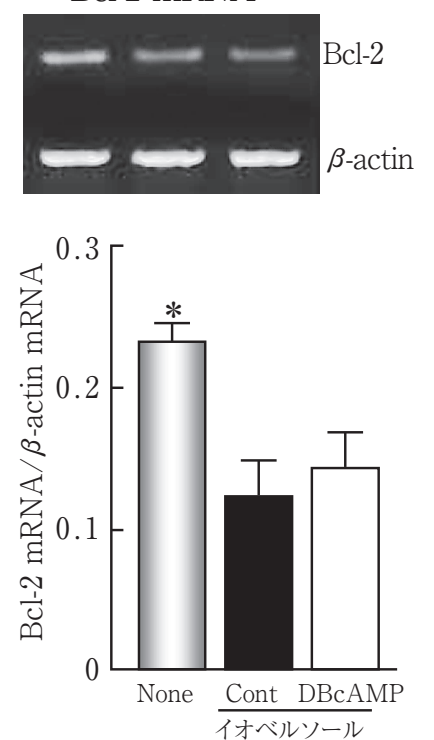

Bax mRNA
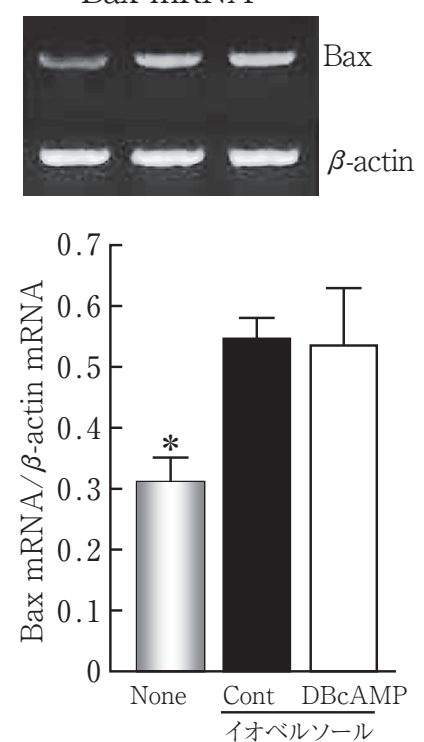

図 5 イオベルソール誘発 Bcl-2 抢よび Bax mRNA 発現変化 に対する DBcAMP の作用, Dominant-negative CREB 移入細胞での検討（文献 3 より引用）

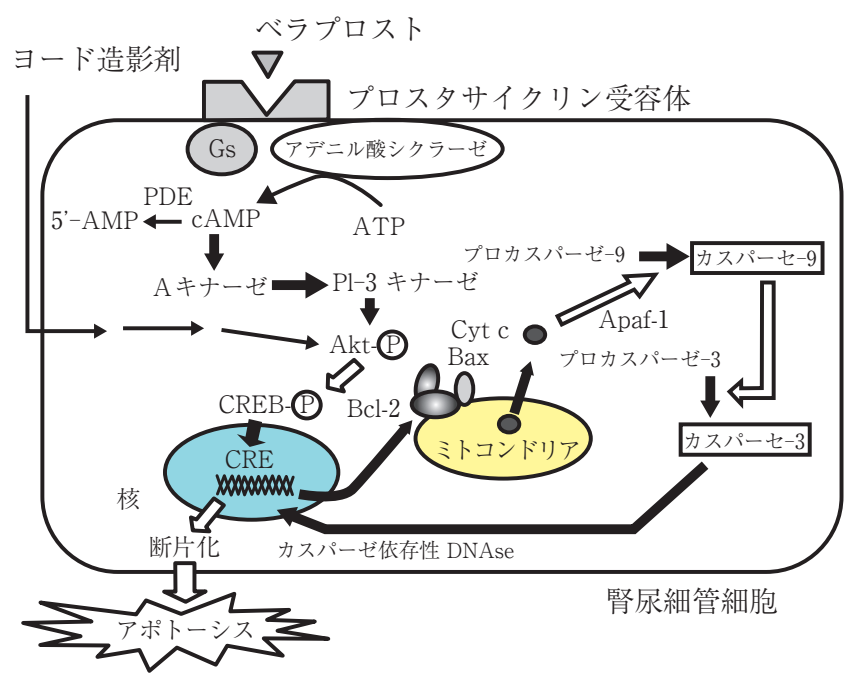

図 6 造影剂腎症の発症機序ならびにベラプロストによる保護 作用機序
細胞にアポトーシスが生じていることが確認された (図 7 )。ささらに, 造影剤を投与したマウスの腎組織で は，カスパーゼ-3 活性が顕著に増加しており，また， bcl-2 mRNA の低下ならびに bax mRNA の増加が認 められた。これらの変化はいずれもべラプロスト $(0.1$ $\sim 0.3 \mathrm{mg} / \mathrm{kg}$ ）の腹腔内投与により用量依存的に抑制さ れ，特に0.3mg/ $\mathrm{kg}$ の用量では抑制作用はほぼ完全であ った（図 8 ).ベラプロストはプロスタサイクリン受容 体（IP 受容体）を刺激するが，この受容体は $\mathrm{G}$ タンパ ク質共役型受容体であり，促進性 $\mathrm{G}$ タンパク（Gs）を
TUNEL 染色

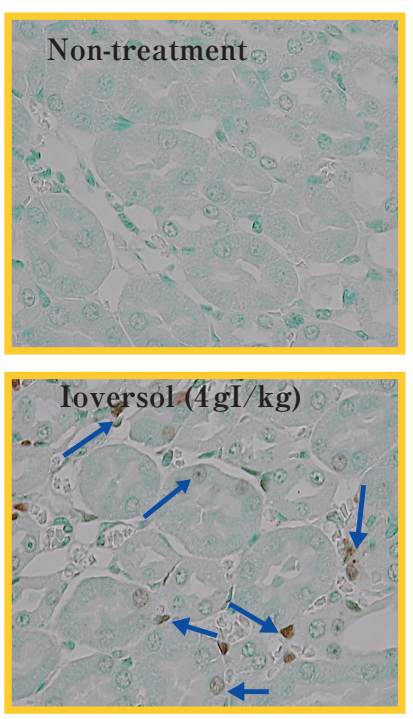

mRNA
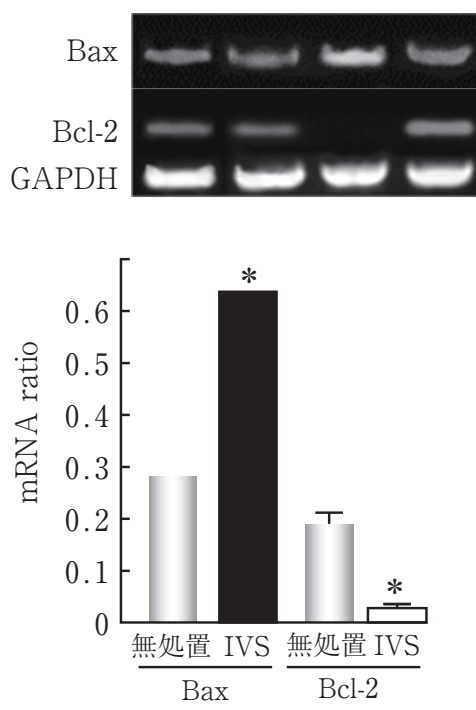

図 7 造影剤腎症モデルマウスの腎における障害と機序 (文献 3 より引用)

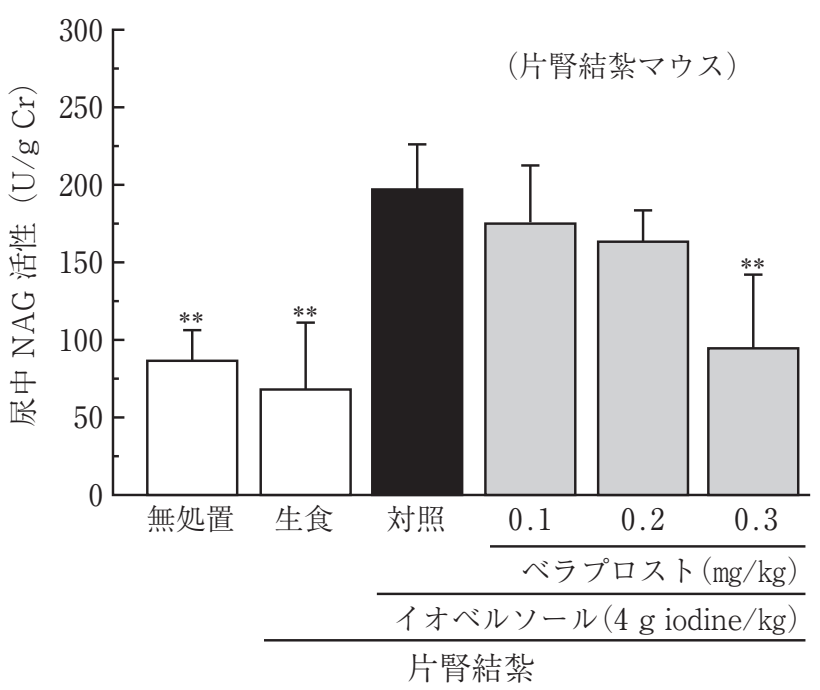

図 8 造影剤腎症モデルマウスにおけるべラプロストの保護作 用，尿中 NAG 排泄増加に対する抑制作用 $(* * \mathrm{p}<0.01)$ (文献 2 より引用) 
介して cAMP 産生を促進する。ヒトの腎臓には IP 受 容体が多く存在し, 特に糸球体, 血管内皮細胞, 遠位 尿細管, 集合管に多い. ベラプロストは慢性動脈閉塞 症に伴う潰瘍, 疼痛及び冷感の改善, 原発性肺高血圧 症に保険適用を有する医薬品であり，まれに頭痛，顔 面潮紅，ほてり等の副作用が出ることがあるが，重篤な 副作用はほとんどないことより臨床応用が期待される。

\section{おわりに}

造影剂による腎障害の発現機序を明らかにするとと もに，発現機序に基づく予防薬の提案ならびにその効 果を示した.ベラプロストは腎に多く分布する $\mathrm{PGI}_{2}$ レ セプターを刺激し, 細胞内 cAMP 産生を高めること により，造影荗腎症に対する有効な予防薬になりうる ものと考えられる。

\section{文献}

1) Yano $T$, Itoh $Y$, Sendo $T$, Kubota $T$, Oishi R: Cyclic AMP reverses radiocontrast media-induced apoptosis in LLC-PK1 cells by activating A -kinase/PI3 kinase. Kidney Int (2003) 64, 2052-2063.

2) Yano $T$, Itoh $Y$, Kubota $T$, Sendo $T$, Oishi $R: A$ prostacyclin analog beraprost sodium attenuates radiocontrast media-induced LLC-PK1 cells injury. Kidney Int (2004) 65, 1654-1663.

3 ) Yano $T$, Itoh $Y$, Kubota $T$, Sendo $T$, Koyama $T$, Fujita T, Saeki K, You A, Oishi R:A prostacyclin analog prevents radiocontrast nephropathy via phosphorylation of cyclic AMP response element binding protein. Am J Pathol (2005) 166, 1333-1342.

4) Itoh Y, Yano T, Sendo T, Sueyasu M, Hirano K, Kanaide $\mathrm{H}$, Oishi R : Involvement of de novo ceramide synthesis in radiocontrast-induced renal tubular cell injury. Kidney Int (2006) 69, 288-297. 